\title{
PENGEMBANGAN MODUL PEMROGRAMAN WEBSITE CONTENT MANAGEMENT SYSTEM UNTUK MENINGKATKAN KEMAMPUAN GURU DALAM PENGELOLAAN WEBSITE SEKOLAH DI SMA NEGERI 1 CEPOGO BOYOLALI
}

\author{
Putri Utami ${ }^{1}$ dan Dian Hidayati ${ }^{2}$ \\ ${ }^{1,2}$ Magister Manajemen Pendidikan Universitas Ahmad Dahlan \\ Jl. Pramuka no. 42, Umbulharjo, Kota Yogyakarta 55161 \\ ${ }^{1}$ Email: n_putri12@yahoo.com \\ ${ }^{2}$ Email koresponden: dian.hidayati@mp.uad.ac.id
}

\begin{abstract}
ABSTRAK
Seiring Perkembangan dan kemajuan IPTEK, mampu memberikan efektivitas dan interaktivitas dalam dunia pendidikan. Website sekolah adalah salah satu produk teknologi yang harus digunakan oleh sekolah. Penelitian ini bertujuan untuk mengembangkan dan mengetahui kelayakan modul pemrograman website untuk meningkatkan kemampuan guru dalam pengelolaan website sekolah. Penelitian ini termasuk jenis penelitian pengembangan Research and Development $(\mathrm{RnD})$ dengan menggunakan metode pengembangan ADDIE. Teknik pengumpulan data menggunakan wawancara dan angket kemudian dianalisis menggunakan data kualitatif dan kuantitatif. Subjek penelitian ini adalah ahli media, guru dan operator di SMA Negeri 1 Cepogo. Hasil penelitian ini menunjukkan bahwa penelitian dan pengembangan telah dilakukan dengan langkah-langkah model ADDIE, yaitu (Analysis, Design, Development, Implementation, Evaluation). Rata-rata penilaian oleh uji validasi ahli sekor yang diperoleh 87,1 termasuk dalam kategori "Baik Sekali" respon guru uji lapangan tahap1 dan uji lapangan tahap 2 diperoleh nilai rata-rata 81,8 dengan kategori "Baik Sekali". Apabila analisis data kuantitatif diambil rata-rata hasil penilaian uji validasi ahli dan uji coba pengguna maka diperoleh sekor 84,45 dengan kategori "Baik Sekali" dan menunjukan bahwa modul pemrograman website layak digunakan oleh guru dalam pengelolaan website sekolah.
\end{abstract}

Kata Kunci: Modul, Pemrograman Website, Pengelolaan Website Sekolah.

\begin{abstract}
The development and advancement of science and technology can provide effectiveness and interactivity in the world of education. The school website is a technology product that must be used by schools. This study aims to develop and determine the feasibility of a website programming module to improve teachers' abilities in managing school websites. This research is a Research and Development (RnD) development research using the ADDIE development method. Data collection techniques using interviews and questionnaires then analysed using qualitative and quantitative data. The subjects of this study were media experts, teachers and operators at SMA Negeri 1 Cepogo. The results of this study indicate that research and development have carried out using the ADDIE model steps, namely (Analysis, Design, Development, Implementation, Evaluation). The average assessment by the score expert validation test obtained was 87.1 included in the "Very Good" category, the response of the phase 1 field test teacher and stage 2 field test obtained an average value of 81.8 in the "Very Good" category. The quantitative data analysis took the average results of the assessment of expert validation tests and user trials. The score is 84.45 with the category "Very Good" and shows that the website programming module is suitable for use by teachers in managing school websites.
\end{abstract}

Keywords: Module, Website Programming, School Website Management.

\section{PENDAHULUAN}

Era globalisasi dan teknologi seperti sekarang ini istilah internet sudah tidak asing lagi bagi kita, mulai dari orang dewasa sampai pelajar sudah menggunakan teknologi ini. Bahkan produsen komputer juga tidak ketinggalan mereka berlomba-lomba menciptakan komputer 
yang canggih untuk memenuhi kebutuhan yang semakin bertambah. Di zaman dahulu informasi yang didapat hanya melalui media cetak seperti koran atau buku serta media elektronik seperti radio dan televisi. Media-media tersebut berkembang terus seiring dengan kebutuhan masyarakat akan informasi. Namun media-media ini banyak kekurangannya, karena hanya memberikan informasi yang ada maupun berita yang sudah lama dan informasi hanya sekali saja tidak dapat diulang lagi.

Perkembangan informasi tentang Ilmu Pengetahuan dan Teknologi (IPTEK) melalui internet dapat memajukan dunia pendidikan. Anak sekolah sekarang sudah banyak membuka informasi melalui situs atau website milik sekolah, website menjadikan masyarakat atau wali murid mengetahui lebih banyak tentang sekolah di mana anaknya sekolah dan merasa dekat dengan pihak sekolah di manapun berada.

Keberadaan internet di sekolah akan menjadi suatu kebutuhan, hal ini dapat dilihat dari seringkali permintaan laporan data sekolah oleh pihak terkait untuk dikirim melalui internet. Dengan memiliki jaringan internet di sekolah, pihak sekolah sebenarnya tidak hanya untuk mengirim laporan juga bisa memperoleh informasi pendidikan lebih cepat, mengunduh gambar atau materi ajar untuk media pembelajaran dan masih banyak lagi keuntumgan yang bisa sekolah dapatkan.

Internet sebagai salah satu jaringan komputer yang paling banyak digunakan secara luas diseluruh dunia saat ini memiliki banyak sekali manfaat. Ada beberapa aspek manfaat positif dari internet dalam bidang pendidikan yaitu sebagai sumber informasi, mempermudah komunikasi antar personal, meningkatkan kreatifitas individu, dan inovasi dalam pembelajaran semakin berkembang dengan adanya inovasi $e$-learning yang semakin memudahkan proses pendidikan.

Hasil wawancara yang dilakukan oleh peneliti, pada tanggal 22 0ktober 2019 di SMA Negeri 1 Cepogo yang berada di Kecamatan Cepogo, Kabupaten Boyolali. Permasalahan yang terjadi yaitu pertama di SMA N 1 Cepogo sudah terdapat koneksi jaringan internet yang dapat digunakan oleh guru untuk mengakses internet. Kedua sekolah sudah memiliki situs website resmi sebagai media promosi dan profil sekolah, tetapi dalam pengelolaan website sekolah kurang maksimal karena guru masih mengalami kesulitan dalam mengubah dan mengedit website, guru masih bingung dalam langkah-langkah pemrograman website. Ketiga guru memiliki semangat dalam pengelolaan website sekolah, hal itu ditunjukan dengan semangat guru dengan terus belajar mencoba secara autodidak (belajar sendiri) untuk mengelola website sekolah. Keempat sekolah belum memiliki bahan belajar untuk guru dalam mengelola website sekolah sehingga hal ini menjadi masalah bagi guru dalam 
mengelola website sekolah karena kemampuan guru yang masih rendah dalam mengelola website. Kelima pengelolaan website sekolah hanya dikelola oleh bagian tata usaha sekolah pengelolan website sekolah juga kurang maksimal, karena guru kurang mengetahui dalam mengubah dan mengedit website sekolah.

Seorang guru harus mampu menyesuaikan diri dengan pesatnya perkembangan tekonologi dan informasi saat ini. Karena jika tidak demikian maka siswa bisa jadi memiliki pengetahuan dan kemampuan yang lebih tenggi dari pada guru karena akses terhadap pengetahuan melalui internet sudah sangat mudah didapat. Dengan adanya modul pemrograman website ini bisa menjadi alternatif guru dalam belajar dan menambah pengetahuan tentang pengelolaan website sekolah yang bisa dibaca dan dipelajari kapan saja.

Guru memiliki masalah dalam hal pengelolaan website sekolah. Guru dan staf tata usaha kurang maksimal dalam mengelola website sekolah dikarenakan masih kesulitan dalam langka-langkah pengoprasian, pemrograman dan pengeditan tampilan website. Oleh karena itu perlu dilakukan penelitian terkait dengan masalah tersebut guna mencari solusi yang tepat agar dapat mengatasi permasalahan yang ada. Setelah mengetahui potensi dan masalah sesuai dengan penelitian yang hendak dilakukan, dalam pengumpulan data peneliti melakukan dengan cara melakukan pengamatan dan wawancara kepada kepala sekolah dan guru. Hasil pengamatan dan wawancara tersebut dapat digunakan sebagai bahan pertimbangan untuk perencanaan pengembangan modul pemrograman website yang dapat digunakan oleh guru untuk mengelola website sekolah. Pengembangan modul pemrograman website dirasa sangat penting karena sekolah belum memiliki bahan belajar atau panduan dalam mengelola website serta kemampuan guru yang masih rendah dalam pemrograman atau pengelolaan website sekolah. Modul pemrograman website ini bertujuan untuk memudahkan guru dalam mengedit, mengubah, mengurangi tampilan website, dan lain sebagainya. Agar website sekolah terus update, terkelola dengan maksimal serta memudahkan masyarakat dalam mencari informasi tentang sekolah.

Pemilihan modul pemrograman website karena dapat membantu mengatasi permasalah yang dihadapi guru dalam pengelolaan website sekolah. Modul tersebut merupakan bahan ajar yang telah disusun secara sitematis yang mencakup isi materi, metode dan evaluasi yang dapat digunakan secara mandiri. Modul Sebagai salah satu bahan ajar cetak yang dirancang untuk dapat dipelajari sendiri oleh peserta pembelajaran dimanapun berada (Setyawati dkk, 2012). Modul ini merupakan media untuk belajar mandiri karena di dalamnya telah dilengkapi dengan petunjuk untuk belajar sendiri. Dimana pembaca nantinya 
dapat melakukan kegiatan belajar tanpa kehadiran pengajar secara langsung atau daring (Makmun, 2005).

Modul mempunyai banyak arti berkenaan dengan kegiatan belajar mandiri. Orang bisa belajar kapan saja dan dimana saja dan kapan saja secara mandiri, kegiatan belajar itu sendiri juga tidak terbatas pada masalah tempat bahkan orang yang berdiam di suatu tempat yang jauh dari pusat penyelenggaraan pun bisa mengikuti pola belajar seperti ini dengan menggunakan modul (Prastowo, 2014). Tujuan pengembangan modul penelitian ini agar memudahkan guru dalam pengelolaan website sekolah. Modul sebagai panduan guru dalam langkah-langkah pemrograman website sekolah guru dapat mengedit tampilan website sesuai dengan kebutuhan dan agenda sekolah yang ada. Dengan mengikuti modul sebagai panduan langkah-langkah pengeditan website, modul pada penelitian pengembangan ini disusun secara sistematis, nudah digunakan, dipahami, dan praktis agar guru dapat belajar dengan mandiri.

Menurut (Yuhefizar, 2013) Website adalah keseluruhan halaman-halaman web yang terdapat dari sebuah domain yang mengandung informasi. Sebuah website digunakan atas banyak halaman web yang saling berhubungan, hubungan antara satu halam web dengan halaman web yang lain disebut dengan hyperlink. Menurut (Anonim, 2001) Website adalah fasilitas hypertex untuk menampilkan data berupa teks, gambar, bunyi, animasi dan multimedia lainnya, yang diantara data tersebut saling berhubungan satu sama lain. Website merupakan tempat penyimpanan data dan informasi dengan topik tertentu.

Menurut (Iqbal, 2009) Content Management System (CMS) adalah sebuah system yang memberikan kemudahan kepada para pengguna dalam mengelola dan mengadakan perubahan sebuah isi sebuah website dinamis tanpa sebelumnya dibekali pengetahuan tentang hal-hal yang bersifat teknis, dengan berbagai keuntungan yang dimiliki CMS. Content Management System merupakan aplikasi berbasis web yang memiliki sistem sedemikian sehingga memberi kemudahan keapada para pengguna sekaligus juga pengelola. Pemisahan antara isi dengan desain turut menjaga konsistensi tampilan yang mempermuda pengguna kembali berbagai informasi yang ada dalam server. Fitur-fitur yang terdapat dalam CMS juga sangat bervariasi, mulai dari manjemen layout situs (yang berfungsi untuk mengubah layout) fitur pencarian, editing berita, editing foto, editing produk dan sebagainya. Sedangkan Menurut (Riyanto, 2006) Content Management System (CMS) merupakan sekumpulan script dan sebuah database yang dijalankan pada sebuah website dengan menggunakan kode salah satu bahasa pemrograman internet. Dalam sebuah system CMS dapat terdapat content untuk memberikan kemudahan kepada para penulis/editor untuk 
menambah memperbaharui dan menghapus content yang ada tanpa campur tangan langsung dari webmaster.

\section{METODE PENELITIAN}

Dalam penelitian ini jenis data yang digunakan dalam penelitian pengembangan modul pemprograman website ini menggunakan data kualitatif dan kuantitatif. Adapun penjelasan mengenai jenis data yang digunkaan dalam penelitian pengembangan modul adalah sebagai berikut. Data kualitatif data ini berupa hasil tanggapan, data kualitatif diperoleh berdasarkan hasil pengisian penilaian atau tanggapan, saran dan masukan dari ahli media, dan respon guru. Hasil dari data yang diperoleh sebagai bahan revisi produk yang dikembangkan. Dan data kuantitatif data ini berupa penilaian, data kuantitatif diperoleh dari hasil angket ahli media, angket ahli materi dan penilaian guru. Hasil akhir dari penilaian ahli dan guru merupakan penentuan kualitas dan kelayakan modul pemrograman website.

Kelayakan modul pemrograman website dilakukan dengan menggunakan data dari lembar penilaian validasi ahli media, dan penilaian guru. Analisis data dari pakar ahli dan penilaian angket guru menggunakan skala likert yang memiliki kategori rentang nilai dari yang tertinggi sampai yang terendah. Rentang yang digunakan adalah berbentuk angka (4, 3, 2, 1). 4 (Baik Sekali), 3 (Baik), 2 (Kurang) 1 (Sangat Kurang) Data yang di peroleh selanjutnya diolah dengan menggunakan rumus (Arikunto, 2013) adalah sebagai berikut.

$$
\mathrm{P}=\frac{\sum \text { Skor }}{\sum \text { Skor Maksimal }} \mathrm{X} 100
$$

Apabila sudah nilai dari masing-asing penilai selanjutnya akan dihitung rata-rata dengan menggunakan rumus (Arikunto, 2011) yaitu:

$$
X=\frac{\sum x}{n}
$$

Keterangan:

$$
\begin{array}{ll}
\mathrm{X} & =\text { rata-rata nilai } \\
\sum \mathrm{x} & =\text { jumlah nilai } \\
\mathrm{n} & =\text { jumlah penilai }
\end{array}
$$

Hasil presentase skor akan dikonversikan berdasarkan kriteria penilaian (Arikunto dan Cepi, 2014) adalah sebagai berikut: 
Tabel 1. Kriteria Kelayakan

\begin{tabular}{cc}
\hline $81-100$ & Baik Sekali \\
$61-80$ & Baik \\
$41-60$ & Cukup \\
$\leq 21-40$ & Kurang Baik \\
\hline
\end{tabular}

\section{HASIL DAN PEMBAHASAN}

Hasil penelitian modul pemrograman website oleh ahli dan guru melalui uji coba produk tahap 1 dan uji coba produk tahap 2 adalah sebagai berikut:

\section{Analisis Data Kualitatif Modul Pemrograman website}

\section{a. Analisis Ahli Media}

Uji ahli media terhadap modul pemrograman website. Adapun aspek yang dinilai dalam uji validasi ahli media mencakup kualitas modul yang dikembangkan dari segi media. Adapun hasil penilaian ahli media mendapatkan nilai 91,6 dengan kategori "Baik Sekali" mendapatkan saran dengan rincian sebagai berikut:

1) Sampul judul (cover) gambar tidak boleh pecah atau belur, judul harus dideskripsikan dengan jelas kegunaan modul untuk siapa dan identitas pengembang.

2) Tata tulis harus dibedakan dari segi font atau warna mulai dari besar yang kecil antara judul, sub judul, dan isi. Dan harus ada jarak antara sub judul

3) Warna isi/materi modul diganti sesuai dengan warna cover judul, halaman modul terletak pada bagian kiri dan kanan bawah modul dan penambahan foter.

4) Halaman belakang dibuat sinopsis yang mendeskripsikan tujuan dan manfaat dari modul.

\section{b. Analisis Ahli Materi}

Adapun aspek yang dinilai dalam uji validasi ahli materi mencakup kualitas modul yang dikembangkan dari segi materi secara spesifik. Adapun penilaian oleh ahli materi mendapatkan nilia 82,6 dengan kategori "Baik Sekali" mendapatkan saran oleh ahli materi sebagai berikut:

1) Ditambahkan nama pemrograman (software) pengembangan website yang digunakan.

2) Membagi materi modul ke dalam 2 bagian yaitu. 1) pemrograman untuk admin (tata usaha) 2) pemrograman untuk guru. 
3) Ditambah pengantar tentang pemrograman dan pengguna.

4) Membuat secara detail setiap langkah-langkah pemrograman.

\section{c. Analisis Uji Coba Tahap 1}

Uji lapangan tahap 1 adalah uji lapangan terbatas atau kelompok kecil diberikan kepada 4 guru di SMA N 1 Cepogo. Berikut hasil penilaian guru terhadap modul yang dikembangkan pada uji lapangan terbatas mendapatkan nilai 83,1 dengan kategori "Baik Sekali" dan masukan dan saran terhadap modul sebagai berikut:

1) Langkah-langkah dalam modul mudah dipahami dan diikuti

2) Pemilihan warna desain tampilan modul kurang menarik

3) Penggunaan huruf pada judul dan langkah-langkah dibedakan agar lebih menarik.

\section{d. Analisis Uji Coba Tahap 2}

Uji lapangan tahap 2 adalah uji lapangan tidak terbatas yaitu dengan memberikan angket penilaian modul kepada seluruh guru di SMA N 1 Cepogo. Berikut ini hasil penilaian guru terhadap modul pada saat uji lapangan tidak terbatas. sebanyak 9 guru terhadap modul yang dikembangkan di atas menunjukan bahwa penilian guru mendapat nilai persentase sebesar 80,5 dengan kategori "Baik"

\section{Data Kuantitatif Penilaian Modul Pemrograman Website.}

Analisis data kuantitatif dilakukan untuk mengelola data yang diperoleh dari hasil penilaian ahli materi, ahli media, dan penilaian guru. Hasil data kuantitatif modul pemrograman website dari penilaian ahli media, ahli materi, dan uji coba produk (uji produk coba tahap 1), dan (uji coba produk tahap 2) dapat diketahui rata-rata penilaian sebagai berikut:

$$
X=\frac{\sum x}{n}
$$

Keterangan:

$\mathrm{X}=$ rata-rata nilai

$\sum \mathrm{x}=$ jumlah nilai

$\mathrm{n} \quad=$ jumlah penilai 
Berikut penjelasan untuk uji coba produk pada tabel sebagai berikut:

Tabel 2. Hasil Penilaian Uji Coba

\begin{tabular}{|cccc|}
\hline No & Penilai & Nilai & Kategori \\
\hline 1 & Ahli materi & 82,6 & Baik Sekali \\
2 & Ahli media & 91,6 & Baik Sekali \\
3 & Uji lapangan tahap 1 & 83,1 & Baik Sekali \\
4 & Uji lapangan tahap 2 & 80,5 & Baik \\
& Jumlah & $\mathbf{3 3 7 , 8}$ & \\
& Rata-rata & $\mathbf{8 4 , 4}$ & Baik Sekali \\
\hline
\end{tabular}

Berdasarkan data tersebut diatas ,maka instrumen uji coba media modul pemprograman pada kategori "BAIK SEKALI"

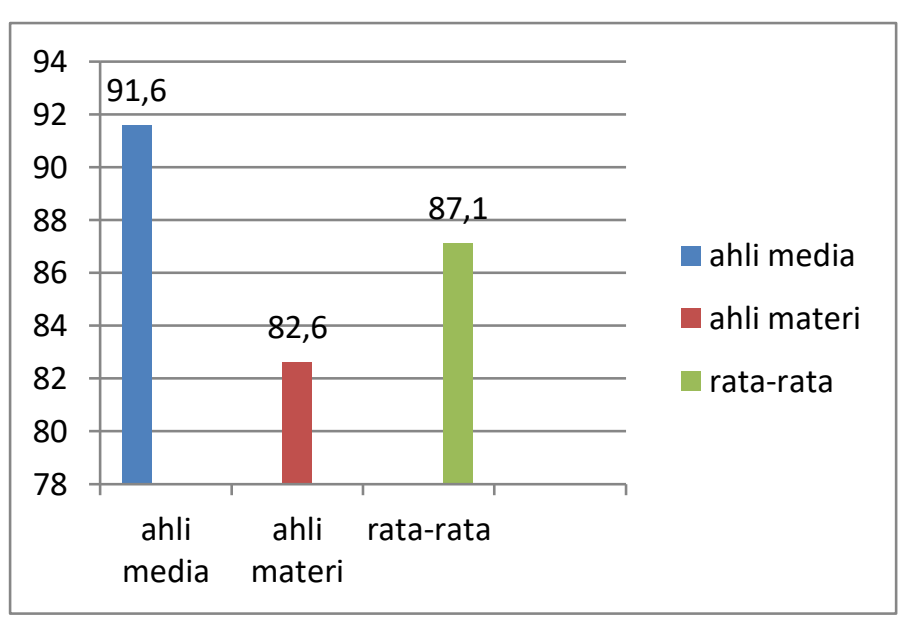

\section{Gambar 1. Penilian oleh ahli materi dan ahli media}

Berdasarkan data diatas penilaian oleh ahli media berada pada nilai 91,6 sedangkan pada ahli materi mendapatkan nilai 82,6 dengan kategori sehingga diperoleh rata-rata 87,1 dengan kategori "BAIK SEKALI"

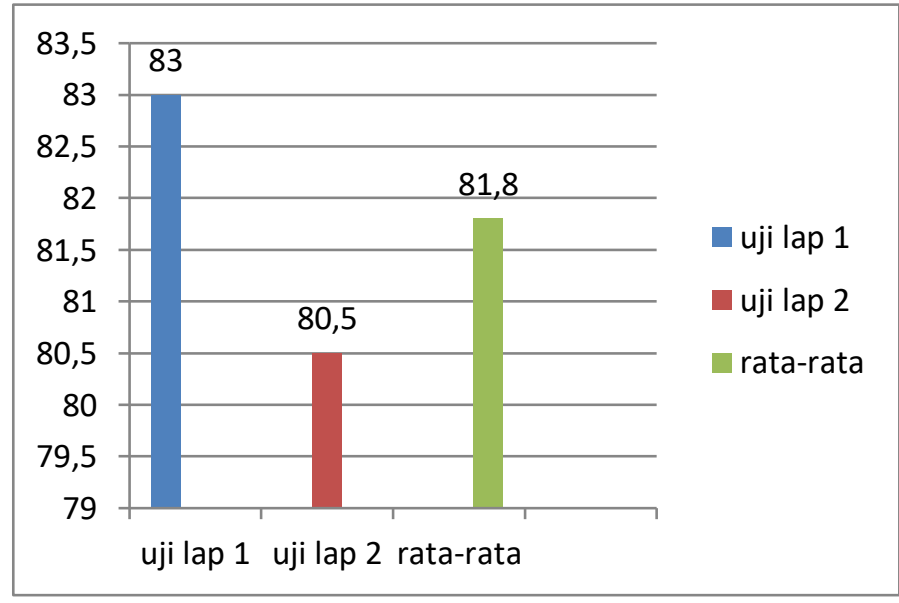

\section{Gambar 2. Angket penilaian guru}

berdasarkan dari hasil uji lapangan 1 dan uji lapangan 2 diperoleh skor rata-rata 81,9 dengan kategori "BAIK SEKALI" 


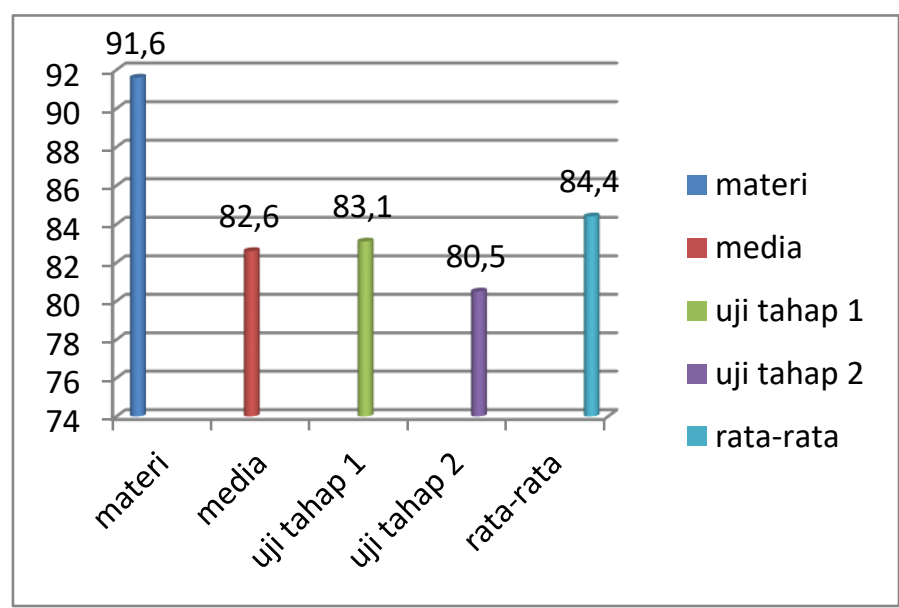

\section{Gambar 3. Penilian validator ahli dan pengguna}

Dari data diatas penilaian validator ahli dan pengguna pada uji tahap satu dan uji tahap kedua diperoleh skor rata-rata 84,4 dengan kategori "BAIK SEKALI".

Instrumen Evaluasi Modul Pembelajaran (Untuk Ahli Materi)

Nama/Judul Modul : MODUL PEMPROGRAMAN WEB

Materi Pokok : Content Management System untuk Website

Hari/Tanggal : Selasa, 22 Oktober 2019

A. Petunjuk

- Lembar evaluasi ini diisi oleh ahli materi

- Evaluasi ini terdiri dari: aspek fisik, pendahuluan, isi, tugas, rangkuman, penutup.

- Jawaban dapat diberikan pada kolom jawaban dengan memberikan tanda check $(\sqrt{ })$ pada kolom yang sesuai menurut penilaian dari ahli materi.

- Kriteria Penilaian:

1: Sangat Kurang

2: Kurang Baik/ Kurang Sesuai/ Kurang Benar/ Kurang Jelas (sesuai pernyataan)

3: Cukup

4: Baik/ Sesuai/ Benar/ Jelas (sesuai pernyataan)

5: Sangat Baik/Sangat Sesuai/Sangat Benar/Sangat Jelas (sesuai pernyataan)

B. Instrumen

Adalah sebagai berikut:

\begin{tabular}{|l|l|l|l|l|l|l|}
\hline No & Pernyataan & 1 & 2 & 3 & 4 & 5 \\
\hline
\end{tabular}




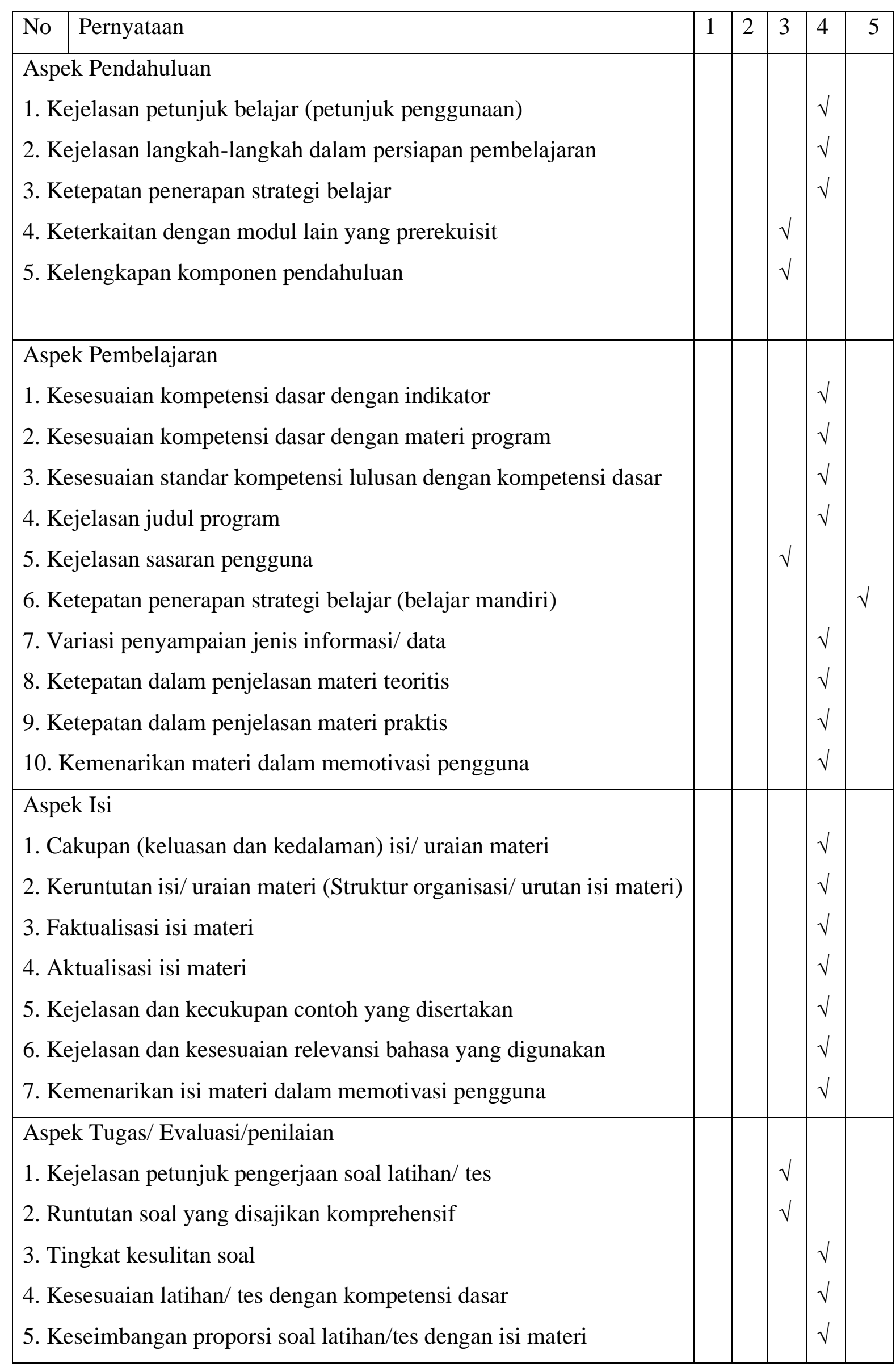


6. Ketepatan pemberian feedback atas jawaban pengguna

7. Kejelasan evaluasi dalam memberikan pemecahan masalah Aspek Rangkuman

1. Kejelasan rangkuman modul (komprehensif)

2. Ketepatan rangkuman modul sebagai materi perulangan

3. Manfaat rangkuman sebagai bahan pengayaan

4. Glosarium/ senarai/daftar istilah

5. Daftar Pustaka

Instrumen Evaluasi Modul Pembelajaran (Untuk Ahli Media)

Nama/Judul Modul: MODUL PEMPROGRAMAN WEB

Materi Pokok : Content Management System untuk Website

Hari/Tanggal : : Selasa, 22 Oktober 2019

A. Petunjuk

- Lembar evaluasi ini diisi oleh mahasiswa

- Evaluasi ini terdiri dari: aspek fisik, pendahuluan, isi/materi, tugas, rangkuman, penutup.

- Jawaban dapat diberikan pada kolom jawaban dengan memberikan tanda check

$(\sqrt{ })$ pada kolom

yang sesuai menurut penilaian dari mahasiswa.

- Kriteria Penilaian:

1 : Sangat Kurang

2 : Kurang Baik/KurangSesuai/Kurang Benar/Kurang Jelas (sesuai pernyataan)

3 : Cukup

4 : Baik/Sesuai/Benar/Jelas (sesuai pernyataan)

5 : Sangat Baik/Sangat Sesuai/Sangat Benar/Sangat Jelas (sesuai pernyataan)

\begin{tabular}{|l|l|l|l|l|l|l|}
\hline No. & Pernyataan & 1 & 2 & 3 & 4 & 5 \\
\hline
\end{tabular}




\begin{tabular}{|c|c|c|c|c|c|c|}
\hline No. & Pernyataan & 1 & 2 & 3 & 4 & 5 \\
\hline \multicolumn{2}{|c|}{ Aspek fisik } & & & & & \\
\hline \multicolumn{2}{|r|}{ 1. Proporsional layout cover/sampul depan (tata letak teks dan gambar) } & & & $\sqrt{ }$ & & \\
\hline \multicolumn{2}{|r|}{ 2. Kesesuaian proporsi warna (keseimbangan warna) } & & & $\sqrt{ }$ & & \\
\hline \multicolumn{2}{|r|}{ 3. Kesesuaian pemilihan jenis font (jenis huruf dan angka) } & & & & $\sqrt{ }$ & \\
\hline \multicolumn{2}{|c|}{ 4. Kejelasan judul modul } & & & & $\sqrt{ }$ & \\
\hline \multicolumn{2}{|r|}{ 5. Kesesuaian pemilihan ukuran font (ukuran huruf dan angka) } & & & $\sqrt{ }$ & & \\
\hline \multicolumn{2}{|c|}{ Aspek Pendahuluan } & & & & & \\
\hline \multicolumn{2}{|c|}{ 1. Kejelasan petunjuk belajar (petunjuk penggunaan) } & & & $\sqrt{ }$ & & \\
\hline \multicolumn{2}{|c|}{ 2. Kemudahan dalam persiapan pembelajaran } & & & & $\sqrt{ }$ & \\
\hline \multicolumn{2}{|c|}{ 3. Ketepatan penerapan strategi belajar } & & & & $\sqrt{ }$ & \\
\hline \multicolumn{2}{|c|}{ 4. Keterkaitan dengan modul lain } & & & $\sqrt{ }$ & & \\
\hline \multicolumn{2}{|c|}{ 5. Kelengkapan komponen pendahuluan } & & & & $\sqrt{ }$ & \\
\hline \multicolumn{2}{|c|}{ 6. Tujuan pembelajaran/kompetensi } & & & & $\sqrt{ }$ & \\
\hline \multicolumn{2}{|c|}{ Aspek Isi/ Uraian Materi } & & & & & \\
\hline \multicolumn{2}{|c|}{ 1. Cakupan (keluasan dan kedalaman) isi/ uraian materi } & & & $\sqrt{ }$ & & \\
\hline \multicolumn{2}{|c|}{ 2. Kejelasan isi materi } & & & $\sqrt{ }$ & & \\
\hline \multicolumn{2}{|c|}{ 3. Keruntutan struktur organisasi/ urutan isi materi } & & & $\sqrt{ }$ & & \\
\hline \multicolumn{2}{|c|}{ 4. Kejelasan dan kecukupan contoh yang disertakan } & & & & $\sqrt{ }$ & \\
\hline \multicolumn{2}{|c|}{ 5. Kejelasan dan kesesuaian bahasa yang digunakan } & & & & $\sqrt{ }$ & \\
\hline \multicolumn{2}{|c|}{ 6. Kemenarikan isi materi dalam memotivasi pengguna } & & & & $\sqrt{ }$ & \\
\hline \multicolumn{2}{|c|}{ 7. Ilustrasi/ contoh/ visualisasi isi materi/ modul } & & & $\sqrt{ }$ & & \\
\hline \multicolumn{2}{|c|}{ Aspek Tugas/ evaluasi/ latihan } & & & & & \\
\hline \multicolumn{2}{|c|}{ 1. Kejelasan petunjuk pengerjaan soal latihan/ tes } & & & $\sqrt{ }$ & & \\
\hline \multicolumn{2}{|c|}{ 2. Runtutan soal yang disajikan } & & & & $\sqrt{ }$ & \\
\hline \multicolumn{2}{|c|}{ 3. Tingkat kesulitan soal/ tes } & & & & $\sqrt{ }$ & \\
\hline \multicolumn{2}{|r|}{ 4. Keseimbangan proporsi soal latihan/ tes dengan isi materi } & & & & $\sqrt{ }$ & \\
\hline \multicolumn{2}{|c|}{ 5. Ketepatan pemberian feedback atas jawaban } & & & & $\sqrt{ }$ & \\
\hline \multicolumn{2}{|r|}{ 6. Kejelasan evaluasi dalam memberikan pemecahan masalah } & & & & $\sqrt{ }$ & \\
\hline \multicolumn{2}{|c|}{ Aspek Rangkuman } & & & & & \\
\hline \multicolumn{2}{|c|}{ 1. Kejelasan rangkuman modul } & & & $\sqrt{ }$ & & \\
\hline 2. $\mathrm{K}$ & epatan rangkuman modul sebagai materi perulangan & & & $\sqrt{ }$ & & \\
\hline
\end{tabular}


3. Manfaat rangkuman sebagai bahan pengayaan

4. Glosarium/ senarai/ daftar istilah

5. Daftar pustaka

\section{SIMPULAN}

Pengembangan modul pemrogrman website mengacu pada Robert Maribe Branch (Sugiyono, 2017). Yaitu ADDIE (Analysis, Design, Development, Implementation, Evaluation). Model ini dipilih karena model ADDIE merupakan model pendekatan sistematis untuk pengembanganinstruksional. Selain itu, model ADDIE merupakan model pembelajaran yang bersifat umum dan sesuai digunakan untuk penelitian pengembangan.ketika digunakan dalam pengembangan,pembelajaran ke tahap sebelumnya .hasil akhir dari suatu tahap merupakan produk awal bagi tahap selanjutnya. Modul pemrograman website telah dinilai dari beberapa aspek yaitu materi dan media. Kelayakan modul pemrograman website dari penilaian ahli media, terhadap kualitas kelayakan produk memperoleh nilai 91,6 dengan kategori "Baik Sekali" Penilaian ahli materi, terhadap kualitas modul pemrograman website mendapat nilai 82,6 dengan kategori "Baik Sekali". Penilaian saat uji coba produk tahap 1 mendapatkan nilai $\quad 83,1$ dengan kategori “ Baik Sekali”. Dan penilaian uji coba produk tahap 2 mendapatkan nilai 80,5 dengan kategori "Baik". Jika penilian ahli dihitung rata-rata mendapatkan nilai 87.1 dan termasuk dalam kategori "Baik Sekali" dan jika penilian ahli dan pengguna di hitung rata-rata mendapatkan nilai nilai rata-rata 84,4 dengan kategori "Baik Sekali”. Jadi dapat disimpulkan bahwa modul pemrograman website layak digunakan guru dalam pengelolaan website SMA N 1 Cepogo.

\section{DAFTAR PUSTAKA}

Arikunto, Suharsimi, 2013. Prosedur Penelitian Suatu Pendekatan Praktik. Jakarta: Rineka Cipta.

\section{S. 2011. Prosedur Penelitian. Jakarta: Rineka Cipta.}

Arikunto, Suharsimi, dan Cepi. 2014. Evaluasi Program Pendidikan. Jakarta: Bumi Aksara.

Bahri Syaiful, Djamarah dan Zain, Aswan. 2002. Strategi Belajar Mengajar. Jakarta: Rineka cipta.

Hendrianto, Eko Dani. 2014. Pembuatan Sistem Informasi Perpustakaan Berbasis Website Pada Sekolah Menegah Pertama Negeri 1 Donorojo Kabupaten Pacitan. Journal on Networking and Security - speed (IJNS) Volume 3 No 4. 
Iqbal. 2009. Rekayasa Conten Manageen System (CMS) Jomla Berbasis Open Source Untuk Pengembangan System Informasi Berbasis Online. Universitas Gaja Mada Yogyakarta: Jurnal Informatika. Vol 3, No.1.

Makmun, Abin Syamsuddin. 2005. Psikologi Pendidikan. Bandung: Yudhistira.

Mulyatiningsih, Endang. 2014. Metode Penelitian Terapan Bidang Pendidikan. bandung: Alfabeta.

Nana Syaodih Sukmadinata (2009). Metode penelitian Pendidikan. Bandung: Remaja Rosdakarya

Prastowo, Andi. 2014. Pengembangan Bahan Ajar Tematik Tinjauan dan Praktik. Jakarta: Kencana Prenamedia.

Riyanto, Slamet. 2006. Kursus Singkat 8 Jam Mambo. Jakarta: Datakom Lintas Buana.

Setyowati, Ratna, dan Parmin, Arif Widiyatmoko. 2012. "Pengembangan Modul Ipa Berkarakter Peduli Lingkungan Tema Polusi Sebagai Bahan Ajar Siswa SMK N 11 Semarang", Journal Unnes Science Education. Vol. 2, No. 2.

Sugiyono. 2014. Metode Penelitian Pendidikan Pendekatan Kuantitatif, Kualitatif Dan $R \& D$. Bandung: Alfabeta.

Usman M. U. 2006. Menjadi Guru Profesional. Bandung: Remaja Rosdakarya.

Yuhefizar. 2013. Cara Mudah \& Murah Membangun \& Mengelola Website. Yogyakarta: Graha Ilmu. 